\title{
SHOPPING TOURISM IN HUNGARY DURING THE PERIOD OF THE ECONOMIC CRISIS
}

\section{Gábor Michalkó( ${ }^{(1)}$ - Tamara Rátz ${ }^{(2)}$ - Mátyás Hinek ${ }^{(3)}$ - Mihály Tömörìi(}

(1) Scientific Advisor, Hungarian Academy of Sciences, Research Centre for Astronomy and Earth Sciences, Geographical Institute, Budapest, Hungary, michalko@iif.hu

(2) Director, Kodolányi János University of Applied Sciences, Centre for Business Studies, 8000 Székesfehérvár, Fürdő u.1., Hungary, tratz@kodolanyi.hu

(3) Head of Department, Kodolányi János University of Applied Sciences, Department of Management Sciences, Székesfehérvár, Hungary, hinekm@mail.kodolanyi.hu

(4) Assistant Lecturer, College of Nyíregyháza, Institute of Tourism and Geography, Nyíregyháza, Hungary, tomori@nyf.hu 


\title{
SHOPPING TOURISM IN HUNGARY DURING THE PERIOD OF THE ECONOMIC CRISIS
}

\begin{abstract}
The study analyses the impacts brought about by the economic crisis starting in 2007 on Hungarian shopping tourism. Considering the long-term symbiotic relationship of the national retail trade and international inbound tourism, the crisis, that has affected each segment of the national economy, has also influenced both the characteristics of tourist shopping and the structure and volume of retail trade, with an indirect impact on the country's GDP. The study investigates the purchases of day trippers arriving from the neighbouring countries, and focuses on changes that occurred between 2006-2010. The survey is based on the assumption that the sending markets have become more price-sensitive as a consequence of the crisis, and the changes brought about will be diverse, depending on the economic-social processes of each sending country. Demand is influenced by crisis management strategies, by the pricevalue ratio of goods and services available in the market, and by the business practices of retail companies. Based on secondary analysis of the databases of the Hungarian Central Statistical Office and the Hungarian National Bank, the paper provides an overview of how Hungarian shopping tourism was shaped by the above factors in the period of crisis.
\end{abstract}

Keywords: shopping tourism, retail, Hungary, economic crisis, currency 


\section{Introduction}

The symbiosis of tourism and retail is a prosperous phenomenon in many parts of the world. Tourist demand, realised in a wide variety of retail units, is present in North America (Timothy and Butler, 1995; Dimanche, 2003), in EU member states (Tréboul, 1994; Coles, 2004), as well as in the Asia-Pacific region (Hobson, 1996; Kim and Prideaux, 1999; Reisinger and Turner, 2002; Henderson et al, 2011). Travellers are looking for shopping opportunities in the hope of a good deal, for entertainment purposes, or maybe just due to customary obligations (e.g. social expectations, following others' consumption patterns) (Murphy et al, 2012). Among the factors that influence the amount spent at local producers, markets, smaller or larger shops or department stores, financial gain ranks undoubtedly high, since it is regarded as savings by most shopping tourists. Although in certain countries domestic tourism can also provide a framework for shopping-oriented mobility (e.g. as a result of unequal sales taxes levied by different states), the majority of shopping tourists achieve savings through cross-border travel.

The lower price level of a product or service (e.g. a car repair) in a neighbouring country can be tempting for people living in borderlands even in the best of times, but temporary or permanent recession can further stimulate trips motivated by shopping. The global economic crisis that started in the second part of 2007 inspired individuals and households to follow various 'survival' strategies, among which savings realised through shopping abroad helped avoid and/or mitigate a drastic decline in one's level of consumption (Hampson and McGoldrick, 2011; Bronner and Hoog, 2012). Temporary or permanent price level differences in the retail sector of neighbouring eurozone member states, and the devaluation of currencies of countries outside the eurozone due to the effects of the economic 
crisis contributed to the continuation and growth of European shopping tourism (Berghauer, 2008; Tömöri, 2011).

In Hungary, which is a traditional destination of shopping tourism in East Central Europe, incoming shopping tourism has always been affected by the fluctuation of exchange rates within the region (Kovács, 2008). The devaluation of the Hungarian forint (HUF) as a consequence of the economic crisis was accompanied by an upturn in retail turnover in Hungarian borderland shops which usually provide better price levels, together with wider retail services, than neighbouring Eurozone member states (especially in the case of Hungarian products popular in these countries) (Sikos T. and Kovács, 2008). Austrians, Slovenians and Slovaks living near the borders immediately interpreted the devaluation of the HUF against the EUR as a 'discount' and started to do their weekly shopping in Hungarian hypermarkets. Since the exchange rates of national currencies of neighbouring countries outside the Eurozone (Ukraine, Romania, Serbia, Croatia) did not change significantly against the HUF, the motivation of shopping tourists arriving from these countries were influenced by more complex factors.

The present paper places the phenomenon of shopping tourism in a modern theoretical context, explores the spatial and temporal aspects of the tourist behaviour of travellers motivated by shopping, and evaluates the changes that emerged as a consequence of the global economic crisis between 2006 and 2010. The study is based on the review of the Hungarian and the international literature and on the authors' analysis of the databases of the Hungarian Central Statistical Office of international visitor arrivals and spending (HCSO, 2007-2011a) and those of the Hungarian and the Romanian National Banks on currency exchange rates within the study period (HNB, 2011; RNB, 2011). The databases of the HCSO (based on data collected through questionnaire survey on representative sample of foreigners leaving Hungary, and available in detail only in Hungarian) provide information on the 
number of arrivals and the total spending by country of origin, as well as the distribution of arrivals and of spending by motivation and by country of origin, making it possible to analyse the spending patterns of shopping tourists arriving from selected countries.

\section{The model of international shopping tourism}

International travellers, with few exceptions, usually participate in shopping as part of their trips; nevertheless the mode and degree of their involvement in retail-oriented tourist activities show significant differences. While most tourists who participate in shopping do it as a pleasure and relaxation activity that enhances their overall experience (i.e. are involved in 'tourism shopping'), it may also be the main motivation for some types of travel, particularly for cross-border trips, embodying the notion of 'shopping tourism' (Timothy and Butler, 1995; Timothy, 2005; Saayman and Saayman, 2012). In the literature, various types of the shopping and tourism relationship are discussed, based on the characteristics of shoppers, the importance given to the various aspects of the shopping experience (e.g. Lesser and Hughes, 1986; Christiansen and Snepenger, 2002; Oh et al, 2004), the types of destinations (e.g. Bauer and Meier, 2011; Rabbiosi, 2011), the forms of shopping-motivated travel (e.g. Ko, 2000), the economic and sociocultural impacts of tourist shopping (e.g. Dudding and Ryan, 2000) or the institutional framework affecting the development of the shopping tourism phenomenon, either positively or negatively (e.g. Dimanche, 2003). For our study, the distinction between utilitarian shopping and leisure shopping (Timothy, 2005) seemed to be most appropriate, as it was assumed that the economic crisis and its consequences reflected by the fluctuation of currency exchange rates would mainly affect utilitarian cross-border shopping tourism. Utilitarian shoppers are primarily motivated by financial gain (e.g. through saving money or reselling items), while leisure shoppers basically regard their shopping activity as a significant 
part of their tourist programme during their stay (Michalkó, 2004; Murphy et al, 2012). The majority of goods consumed in the framework of utilitarian shopping (e.g. food, clothing, medicine) are intended for everyday consumption or reselling, but there are also items (e.g. antiques) the function of which go beyond everyday necessities (Yu and Littrel, 2003; Michalkó and Váradi, 2004; Michalkó et al, 2005). During leisure shopping tourists predominantly buy gifts (souvenirs) that, on the one hand, contribute to capturing the memories of the trip and, on the other hand, serve as presents for others (Michalkó, 2002; Swanson and Horridge, 2004). While utilitarian shopping is always pre-planned, leisure shopping occurs mostly spontaneously as part of the tourist programme (Hsieh and Chang, 2006; Michalkó and Rátz, 2006), although there are also planned (Rabbiosi, 2011) or even circumstance-induced purchases in this category (the latter occurs e.g. when the traveller's luggage is lost, some items cannot be used anymore, the traveller faces unexpected weather conditions, or wants to pursue a not pre-planned tourist activity). The choice of shopping location and that of products and services purchased are affected by individual characteristics, expressive motives for shopping (such as relaxation, escape, social networks and status) as well as instrumental motives (e.g. meeting social obligations or experiencing the local culture) (Moscardo, 2004).

\section{Figure 1 about here}

Shopping tourism accompanied by relatively short stay (typically occurring in the form of day trips) can be described by the so-called seesaw model (Figure 1). According to the seesaw model of shopping tourism there is a hypothetical equilibrium between the place of departure and the destination when the flow of tourists is minimal (naturally this equilibrium occurs quite rarely in reality, similarly to a playground where one end of a seesaw is either up or 
down). The system loses this balanced position when, taking into account the retail supply of the destination, the shopper living at the place of departure can realise a profit that is worth travelling for. Profit generated by shopping tourism is quite complex: many factors can lead to one's decision to become involved in this activity, such as lower price level (which might be a permanent phenomenon, or may be generated by seasonal sales or temporary gain from exchange rate fluctuations) (Irimiás, 2009), better product quality, attractive brands, the availability of certain products that are scarce or not available at the place of departure (Keller, 2005; Luthar, 2006), or even a more pleasurable shopping environment (Snepenger et al, 2003). Travel purpose, travel style, age and gender may all significantly influence both the amount that travellers spend on shopping and the items that they choose to buy (Lehto et al, 2004). The system loses its balanced position only after thorough consideration, since travelling between the departure place and the destination involves cost, loss of time, efforts, and some risk (see e.g. Švab, 2002 or Luthar, 2006). Travel expenses, travel time, tiredness caused by a change in the environment, problems associated with border crossing, customs control, parking, theft, warranty issues etc. are to be compared with the expected gain, and it is the total effect of these factors that maintains or unsettles the balance of the seesaw model. However, a shopper who decides to travel finds shopping opportunities not only at the destination, but also in the 'corridor'. Travellers can shop profitably at airport duty-free outlets, on board of aircrafts or ships, or along the roads heading towards border crossing points. The seesaw model of shopping tourism is equally valid for domestic and international tourism, the only difference between the two types lies in the existence of national borders. Shopping abroad is often accompanied by using different currencies, languages and necessary adaptation to unfamiliar consumer cultures (Jansen-Verbeke, 1998). 


\section{Shopping tourism in Hungary in the shadow of the economic crisis}

Hungary managed to keep its leading position in the shopping tourism market of East Central Europe after the regime change in 1989-90, aided by the central geographical location of the country, the well-established retail network, the pleasant shopping milieu, as well as the quality and variety of products and their favourable price/value ratio (Michalkó and Timothy, 2001). The facts, that Europe's East-West and North-South transit routes go through Hungary and that the country has seven neighbours, provide opportunities for cross-border activities, among which retail plays a prominent role. Demand is supported by the geographical proximity of the sending and receiving areas: no matter which border section is examined, there are populous 'foreign' cities along the country's borders whose citizens prefer doing their shopping in Hungary (Pál and Pál, 2007; Sikos T. and Tiner, 2007; Tömöri, 2012). Retail chains in Hungary have also recognised the significance of this complementary demand in the borderland areas, therefore they take into account the business potential of shopping tourism throughout their investment planning (Nagy, 2000). The presence of global (Auchan, Metro, Tesco) and regional (Aldi, Lidl, Penny) retail chains guarantees the availability of international brands together with popular Hungarian products, and provides opportunity for price level comparison. Since Hungary shares borders with three Eurozone member states (Austria, Slovakia and Slovenia), the fluctuations in the EUR/HUF exchange rate are reflected in the performance of the retail sector too.

Hungary occupies a medium position among EU member states with respect to the number of foreigners crossing the border; with app. 40 million international visitors in a year, Hungary is not among the top three countries even in East Central Europe, since the Czech 
Republic, Slovenia and Poland all rank higher ${ }^{1}$. The registered traffic of foreigners crossing the borders of Hungary may be characterised by following features:

- The share of day trippers is high (in the period of $2006-2010$ it was between $75.8 \%$ and $78.1 \%$,

- The percentage of transit passengers among day trippers is also high (in the period of 2006-2010, this figure was between $44.1 \%$ and $48.6 \%$ ),

- Within the day tripper segment (excluding transit passengers), the proportion of visitors motivated by shopping is significant and continually increasing (in the period of 2006-2010 their share rose from $47.1 \%$ to $69.9 \%)^{2}$ (HCSO, 2007-2011a).

Shopping is a typical motivation among day trippers, but one can hardly find overnight visitors (tourists) arriving to Hungary with the same motivation. In 2010, 99.7\% of visitors with shopping motivation belonged to the segment of day trippers and only $0.3 \%$ to overnight visitors (HCSO, 2007-2011a).

During the 2007-2009 period of the global economic crisis the number of foreigners visiting Hungary was increasing continuously, the same trend characterising both the total number of visitors (including day trippers) and the total number of foreigners with shopping motivation (including one-day shopping tourists) (Table 1). The increase compared to the previous year was the greatest between 2008 and 2009, with a $32.9 \%$ growth registered in the number of shopping tourists. Despite the fact that the absolute number of visitors with shopping motivation decreased between 2009 and 2010, shopping as a travelling motivation

\footnotetext{
${ }^{1}$ www.tourimis.info

${ }^{2}$ Since the significant weight of day trippers would result in distortions in the interpretation of the role of shopping tourists arriving in Hungary and the effects of the economic crisis, the total traffic without transit passengers is used as a base in the study. While visitors participating in shopping tourism consume the tourist space in a similar way to tourists' use, the behaviour of transit passengers is characterised by the heavy use of transit routes. In 2010, the share of fuel in their total spending was $30.0 \%$, while the proportion of their $\mathrm{F} \& \mathrm{~B}$ expenditure was $21.6 \%$ (HCSO, 2011).
} 
kept its relatively high significance among day trippers $(2009=33.4 \% ; 2010=32.4 \%)$ (HCSO, 2010-2011).

\section{Table 1 about here}

Although the quarterly distribution of shopping tourists is much more balanced than the seasonal fluctuation of all arrivals, a third quarter (summer) peak (from July to September) can be detected. During the economic crisis the only exception to this occurred in 2008, when the percentage of shopping tourists was the highest in the fourth quarter. Most probably this might be explained, on the one hand, by the HUF's significant weakening against the EUR (EUR/HUF 2008 Q3: 236.17; Q4: 262.42), and by the Slovak koruna's (SKK) significant strengthening before joining the Eurozone, on the other hand (SKK/HUF 2008 Q3: 7.79; Q4: 8.65). The two simultaneous processes generated a considerable increase in the number of day trippers visiting Hungary with shopping motivation during the winter holiday period.

\section{Regional characteristics of demand in shopping tourism}

Since the distance between the departure point and the destination plays a crucial role in the regional characteristics of the demand of shopping tourism, it is not surprising that the majority of foreigners visiting Hungary with shopping motivation arrive from neighbouring countries: during the observed period (2006-2010) the share of shopping tourists arriving from neighbouring countries was between $98.4 \%$ and $99.1 \%$.

Figure 2 about here 
The economic crisis stimulated the demand of shopping tourists arriving from neighbouring countries: in 20066.904 million visitors with shopping motivation were registered, while in 2009 this number reached 10.427 million. Although the figure decreased slightly in 2010 , the 9.765 million shopping tourists prove that foreigners' demand was still strong. During the period of the economic crisis, the greatest demand for the Hungarian retail sector originated in Austria and Slovakia (in the peak year of 2009 representing $78.0 \%$ together). The number of shopping tourists arriving from Slovakia increased continuously between 2006 and 2009, while in the case of Austria growth continued uninterruptedly until 2010. Compared to the year 2006, the number of Slovak shopping tourists (4.749 million persons) more than doubled by 2010 (Figure 2). These results are certainly due to the alteration of the EUR/HUF exchange rate and Slovakia's accession to the Eurozone in 2009 (the introduction of the euro in Slovakia resulted in a general price-level increase, which orientated Slovak shoppers living in the borderlands towards Hungarian retail establishments). As for Slovenia's shoppingmotivated demand - being the third Eurozone-member neighbour of Hungary -, it was already low before the economic crisis and declined further after the outbreak of the crisis, in parallel with a significant decrease $(-42.1 \%)$ in the overall number of day trippers and tourists arriving from the country. The reasons behind this phenomenon may lie in the Slovenian market conditions that are out of scope of the study. While the number of shopping tourists arriving form Croatia and Serbia remained relatively stable, there was a continuous decrease from Romania and, after a drastic drop, a moderate increase from Ukraine. The declining position of the Hungarian-Romanian shopping tourism is a result of the weakening of the Romanian leu (RON) against the EUR and the HUF, but the decreasing Romanian purchasing power due to the economic crisis, and the increase in the general price level in Hungary could also play a role. In the case of Ukraine, the significant weakening of the Ukrainian hryvnia (UAH) (app. -50\%) against the EUR and the following crisis can be the reasons behind the 
drastic decline in the number of shopping tourists, which was compensated by a moderate increase in the following years.

During the evaluation of the relationship between shopping tourism and the economic crisis, the change in the ratio of shopping tourists (except for transit passengers) within the total number of visitors may be regarded as an important indicator, since it reveals the increase or decrease of international shopping tourism demand at Hungarian retail establishments. The greatest restructuring in demand took place in the case of Slovakia, since the share of visitors with shopping motivation rose from $33.6 \%$ in 2006 to $68.7 \%$ in 2009 (declining slightly to $64.3 \%$ in 2010). The indicator also shows a significant change in the case of Austria, where this figure rose continuously from $24.9 \%$ to $45.9 \%$ between 2006 and 2010. Meanwhile the percentage of shopping tourists arriving from Romania and Ukraine decreased significantly: in the former case from $57.4 \%$ to $35.7 \%$, in the latter country from $49.2 \%$ to $20.5 \%$. Among the South Slavic states, Croatia and Slovenia reached $60.0 \%$, showing relative stability, while from Serbia $45.0 \%$ of the visitors arrived with shopping motivation. In their cases the economic crisis only minimally affected the ratio of shopping tourists within the total demand, i.e. shopping tourism was in line with the general trends of these countries' tourist mobility.

\section{Regional and structural characteristics of spending: what is in the basket?}

The maintenance of the symbiosis between tourism and retail also serves the interests of the national economy: the spending of visitors arriving to Hungary contributes to the country's budget with approximately one hundred billion HUF annually (HCSO, 2011a). Most of this revenue is created by shopping tourists arriving from neighbouring countries: this figure fluctuated between $95.6 \%$ and $98.1 \%$ during the observed period (2006-2010). The economic 
crisis significantly contributed to the increase of shopping tourists' spending, rising from 107.1 billion HUF to 158.2 billion HUF ( $+47.7 \%$ ) between 2006 and 2009 and falling to 139.3 billion HUF in 2010. The expenditure of Slovakian and Austrian shopping tourists accounted for $62.6 \%$ of the total amount during the peak year of 2009 ; in addition, the expenditures of the Serbs (13.9\%) and the Romanians (12.6\%) are also significant.

However, the importance of shopping and its overall impact on travellers' spending varied from country to country throughout the study period. The share of shopping tourists' spending within the total expenditure of Austrian day trippers and tourists rose, continuously, from $14.2 \%$ to $25.2 \%$, while in the case of Slovenia this figure changed from $39.1 \%$ to $80.7 \%$. Consequently, due to the effects of the economic crisis, the revenue from Slovenian incoming tourism became increasingly generated by shopping tourists, while the travel decisions and tourist activities of Austrians continued to be shaped by other types of motivations. Opposite processes took place in Ukraine: in 2006 shopping tourists accounted for $50.6 \%$ of the total spending, with a major decline to $6.2 \%$ by 2010 , i.e. visitors with other motivations seemed to replace shopping tourists. In the case of other neighbouring countries, the volume of spending roughly coincided with the number of shopping tourists throughout the study period (HCSO, 2007-2011a).

\section{Figure 3 about here}

The economic crisis also affected the per capita expenditure, although changes in this indicator were not so spectacular. During the observed period the per capita expenditure of shopping tourists visiting Hungary was characterized by a decline rather than a growth: they spent 15,339 HUF in 2006 and 14,100 HUF in 2010. Their spending is significantly below the average expenditure of all visitors (excluding transit passengers) that showed an increase in 
the same time period (from $38,827 \mathrm{HUF}$ to $42,465 \mathrm{HUF}$ ). While the per capita expenditures of Austrian, Croatian, Romanian, Slovakian and Slovenian shopping tourists were characterized by relative stability, more hectic changes took place in the case of Serbia and Ukraine (Figure 3). The per capita spending of Serbian shopping tourists, being well above the average, rose year by year: they spent 31,116 HUF in 2006 and 43,757 HUF in 2010 in Hungary. This trend, on the one hand, may be attributed to the involvement of more affluent Serbs in shopping tourism; however, on the other hand, the occurrence of utilitarian shopping (reselling items in crypto-trade) may also be presumed. This assumption is supported by the fact that Serbian shopping tourists' spending is well above the average per capita spending of all international visitors arriving to Hungary (without transit passengers). In the case of Ukraine, the equally above-the-average indicator fluctuated from year to year, reaching an exceptionally high value of 49,607 HUF per capita spending in 2007 , which may also be explained by the occurrence of commercial transactions in the grey zone.

\section{Table 2 about here}

One of the noteworthy aspects of the effects of the economic crisis on shopping tourism is the transformation of the consumer basket's composition. Based on data from the Hungarian Central Statistical Office, changes in the major groups of goods and services can be observed between 2007 and 2010 (Table 2). Among foreigners visiting Hungary with shopping motivation, buying 'food and beverages' in supermarkets and purchasing 'other gifts' played an important role during the years of the economic crisis: their combined share was between 81.6 and $93.8 \%$. It shall be noted though that the latter category usually includes electronics, clothing, household chemicals or other useful items, since buying traditional souvenirs is not a typical activity among shopping-motivated day-trippers. The economic crisis undoubtedly 
resulted in a notable increase in buying food products as its share within the consumption structure of foreigners rose from $27.2 \%$ in 2007 to $49.2 \%$ in 2009 and only fell slightly, to $46.5 \%$, in 2010. The growing interest in purchasing food also resulted in a decline in the 'other gifts' category, forcing many commercial outlets located along the border to somewhat restructure their offering. The data by HCSO (2007-2011a) also show that the high fuel prices in Hungary did not encourage the so-called 'fuel tourism' as the demand for fuel was minimal each year. It shall be noted that shopping as a travel motivation was rarely accompanied by dining out, similarly to the findings of Kemperman et al (2009): only $1.9 \%-2.5 \%$ of shopping tourists visiting Hungary combined the experience of tasting the local cuisine with shopping. The assessment of the consumption structure's national characteristics in the year 2010 indicates that food items were dominant in the Slovak visitors' basket (accounting for $56.2 \%$ of their total demand), while Ukrainians and Serbians were most likely to spend on products belonging to the 'other gifts' category ( $81.0 \%$ and $51.4 \%$, respectively).

\section{Shopping tourism in Hungary: the supply side}

Although the paper focuses on the analysis of incoming shopping tourism demand, it seems to be useful to briefly discuss the retail supply's observable trends along the Austrian-Hungarian and the Slovakian-Hungarian borders as well. Table 3 presents the change in the number of retail outlets in selected cities, identified by Michalkó (2004) as the main destinations of incoming shopping tourism, between 2006 and 2010. The cities of Esztergom and Komárom are situated in Komárom-Esztergom county, Mosonmagyaróvár and Sopron are in GyőrMoson-Sopron county, and Szentgotthárd is in Vas county. All the five cities are located by the border, are easily accessible by car and have a well-developed retail suprastructure serving both domestic and cross-border demand. 


\section{Table 3 about here}

During the 2006-2010 period, as Table 3 indicates, the number of retail outlets decreased in almost every destination, both at city- and county-level, except in Esztergom which showed a V-shaped trend. With the exception of Sopron, no major hypermarkets or shopping centres were opened in the selected cities between 2006-2010 either, i.e. the declining number of smaller shops cannot be attributed to retail deconcentration (Garb, 2007). In total, it seems that the changes in the number of retail outlets were predominantly influenced by the overall impacts of the economic recession, and do not reflect the increasing demand of shopping tourism within the given period.

However, if we look at the average number of residents per retail outlet, we may see a slightly different picture (Figure 4). The assessment is based on the assumption that those indicators that are significantly lower than the county average suggest the presence of additional demand without which the profitable operations of the retail sector in the given city could not be ensured. As Figure 2 shows, the county-level indicators are consistently higher in the study period than the city-level indicators, the largest differences being experienced in the case of Szentgotthárd and Mosonmagyaróvár, two very popular shopping destinations for Austrian tourists.

\section{Figure 4 about here}

The comparison of the data for 2006 and 2010 reveals that within this period Sopron was the only city where the number of residents per retail outlet increased by $29.5 \%$, as opposed to a $15.9 \%$ growth in Györ-Moson-Sopron county. The other four destinations experienced 
considerably smaller changes than their counties' average values: in the case of Esztergom, for example, the indicator only increased by $3.5 \%$, compared with $19.0 \%$ for KomáromEsztergom county. Altogether it might be concluded that although all these destinations suffered, to a certain extent, from the negative impacts of the economic crisis on consumer demand, those cities that could partly rely on cross-border shopping traffic were able to cope more efficiently with these unfavourable effects than their counties in general. This was particularly true along the Slovakian border, where incoming shopping tourist demand grew with a boom in 2009. The Austrian demand, however, proved to be slightly less able to counterbalance the negative impacts of the crisis, probably due to the excessive capacity of retail services and the higher level of competition.

\section{The role of exchange rate fluctuations in shopping tourism}

International tourism is often defined as an invisible export activity, since the products created by the tourism industry (mostly services) do not leave the country, but are purchased and consumed on-site by foreigners travelling to the destination who use their discretionary income earned outside the given destination (Rátz and Puczkó, 2002). However, shopping tourism is an exception in this respect, since it provides an unconventional, but visible contribution to international trade with goods bought by tourists actually crossing borders.

In the framework of shopping tourism tourists use local currencies. The price of exported goods in foreign currency is determined by the domestic price level multiplied by the exchange rate. If domestic prices are constant, changes in the exchange rate increase or decrease the price of products measured in foreign currency. According to Marshall's demand curve, the demand for conventional goods is inversely proportional to price changes 
(Marshall, 1890). Therefore, if domestic prices are constant, foreigners' demand shall increase when the domestic currency weakens and shall decrease when it strengthens.

The relationship between the fluctuation of the HUF-EUR exchange rate and the trends of incoming shopping tourism is examined during the period between 2006 and 2010 . On the one hand, this period is long enough to explore the nature and strength of the relationship, on the other hand, this is a particularly exciting period in terms of exchange rate fluctuation. Between 2006 and 2008, the HUF slowly strengthened, except for a smaller fluctuation at the beginning, then in the third quarter of 2008 it reached its historic peak against the EUR when 1 EUR equalled less than $240 \mathrm{HUF}$ for a short time. Following the outbreak of the economic crisis this trend reversed and after the initial rapid devaluation the exchange rate stabilized; however, particularly in the first quarter of 2009 the HUF weakened significantly again. As a result, the exchange rate (for the first time in history) crossed the threshold of $300 \mathrm{HUF} / 1$ EUR. The devaluation took place relatively fast, but not so rapidly that economic actors, including shopping tourists, would not have been able to react to the altered circumstances.

The examination of the effects of the exchange rate on shopping tourism was based on data from the Hungarian Central Statistical Office (2007-2011a) on the number of day trippers (persons) and the total expenditure of day trippers (thousand HUF). Unfortunately, only quarterly data were available, without geographical disaggregation, i.e. the total number and the total spending of day trippers arriving from all the neighbouring countries of Hungary (including both Eurozone-members and states outside the Eurozone).

In the framework of the analysis, the daily HUF/EUR exchange rates were averaged quarterly, which enabled the comparison with quarterly data on spending and visitor numbers. Unfortunately this resulted in certain loss of information, since the quarterly averages made daily, weekly and monthly fluctuations invisible. 
Based on the available data, several correlations were examined with respect to shopping tourism demand generated by Hungary's Eurozone neighbours. First, the per capita spending of day trippers was compared to changes in the exchange rate. No statistically valid correlation was found, the value of Pearson's linear correlation coefficient was close to 0.00 , which means that it was not proven that higher exchange rate would generate higher per capita spending.

Second, the correlation between the exchange rate and the total spending was examined. In this case a modest correlation was found, the value of Pearson's linear correlation coefficient reached 0.619. Since according to the previous result the per capita spending did not correlate with the exchange rate, therefore the correlation between the aggregate spending and the exchange rate may probably be attributed to changes in the number of visitors. As a result, the third step comprised of the analysis of the linear correlation between the exchange rate and the number of visitors. Again, a modest linear correlation was detected, with the highest value so far. The value of Pearson's linear correlation coefficient was 0.645 , while the value of the coefficient of determination $\left(\mathrm{R}^{2}\right)$ showing the strength of the relationship was 0.415 , i.e. $41.5 \%$ of the variation in visitor numbers was explained by the EUR/HUF exchange rate, which can be regarded as a weakmedium linear correlation.

The correlation between the EUR/HUF exchange rate and the number of day trippers is not strong, but the dependence exists. The value of the determination coefficient is positive, i.e. the weakening of the HUF increased the number of visitors arriving to Hungary with shopping motivation, while a decrease in the exchange rate (strengthening of the HUF) resulted in a reverse process. However, the per capita spending did not correlate with the exchange rate: consequently, the EUR/HUF exchange rate affected the volume of the demand, but not the average expenditure. 
It is important to note that the correlation may also be nonlinear, but as Figure 5 indicates, neither a logarithmic nor any other type of regression analysis would have fitted better. Adding a trend line to the data, $\beta=19.23$, i.e. a 1 HUF change in the exchange rate results in an almost 20,000 persons change in the number of day trippers $\left(\mathrm{df}=18, \mathrm{~F}=12.82, \mathrm{R}^{2}=0.415\right)$.

Although a similar analysis was carried out with respect to Hungary's neighbouring countries outside the Eurozone, no correlation between the exchange rate and the number of day trippers was detectable. In the case of Romania, a major sending country in shopping tourism, the correlation between the RON/HUF exchange rate and the number of visitors was negative, which may probably be explained by the fact that the level of tourist spending from Romania (Transylvania) was much lower in general, and in 2008-2009 the RON/EUR exchange rate was moving parallel with the HUF/EUR rate (and also with other currencies in East Central Europe), therefore no price advantages resulting from exchange rate fluctuations appeared over this period along the Hungarian-Romanian border.

\section{Conclusions}

The findings of the study demonstrated that the economic crisis contributed to the increase of the number of day visitors arriving to Hungary with shopping motivation from neighbouring countries. Inbound shopping-motivated travel predominantly originated from neighbouring Eurozone member states and grew dynamically during the period of the crisis; especially the demand from Slovakia, having joined the Eurozone in 2009, showed a significant increase. However, in the case of Romanian and Ukrainian citizens, characterized by lower living 
standards compared to Hungary, a significant decrease was registered in some aspects of their demand. Altogether, the average per capita spending of visitors with shopping motivation did not show a significant change during the period of the crisis; the Eurozone citizens' willingness to spend was modest, while the spending of the Romanians, Ukrainians and Serbs was well above the average. Due to the effects of the economic crisis, Hungary has become the 'pantry' of neighbouring countries: the value of foreigners' spending on food in Hungarian retail outlets reached app. 100 billion HUF (HCSO, 2010-2011).

The research results also proved that the economic crisis made customers more pricesensitive: those who had the chance seized the opportunity of making 'savings' through shopping tourism and redirected their shopping activities to Hungary. Visitors from Eurozone member states took advantage of the favourable EUR/HUF exchange rate, while citizens from non-Eurozone countries were likely to decrease their spending in Hungarian retail establishments. The crisis did not boost the total expenditure of shopping tourists coming from Eurozone member states, but increased the number of those who participated in the activity; while in the case of non-Eurozone countries the crisis led to rising per capita expenditure. Concerning their motivations, the first group comprises of those who moved their everyday shopping to Hungary, while members of the second group of customers were attracted by the availability of good deals and, occasionally, the opportunity to make profitable transactions in the grey zone.

From a practical point of view, the study proved that price advantages, in this case a consequence of the devaluation of the HUF, are indeed able to influence shopping tourism behaviour. However, exchange rate fluctuations only have short term impacts on the volume of incoming shopping tourism which is also affected by the psychological appeal of making a good deal; in a more stable economic environment such changes are likely to have less significant effect on cross-border consumer behaviour. In general, the devaluation of the 
national currency only brings about temporary and unpredictable competitive advantages, particularly in Hungary, due to the country's small size and high level of import dependency. Then again, the dramatic devaluation of the HUF at the beginning of 2009 seemed to be an exception, leading to a campaign by the Hungarian National Tourist Office in the neighbouring Eurozone countries that focused on the fast improving price-value ratio advantages offered by Hungary. Although the campaign proved to be successful in terms of increasing visitor numbers in the short term, the advantages disappeared with the eventual strengthening of the HUF, highlighting the hazard of using the cheapness of a destination as the core marketing message.

When it comes to the development of retail outlets along the borders, it is dangerous to rely predominantly on external demand since it is subject to exchange rate fluctuation: as it was demonstrated in the case of the Austrian-Hungarian shopping tourism traffic, overdeveloped capacities may suffer more in case of crisis. However, due to the easy access within the Schengen area, retailers should continue to target foreign customers, but should aim to create a mix of wide product supply, attractive shopping environment and favourable prices, as cross-border shopping behaviour is not only determined by price advantages, but depends on a range of other factors as well. Since the favourable EUR/HUF exchange rate did have a positive impact on the arrival of 'new shoppers', retail businesses had the opportunity to keep these customers (but may also lose them if the only advantage of doing their shopping over the border remains the price difference which is dependent on the exchange rate fluctuation)

\section{Acknowledgements}


The research was conducted within the 'OTKA K100953' project entitled 'Invisible tourism mobility in Hungary'.

\section{References}

Bauer, M. and Meier, M. (2011), 'Shopping tourism', in Papathanassis, A. ed, The Long Tail of Tourism: Holiday Niches and their Impact on Mainstream Tourism, Gabler Verlag, Wiesbaden, pp 69-76.

Berghauer, S. (2008), 'Cross border relationship and tourism: shopping tourism in Beregszász', Acta Beregsasiensis, Vol 7, No 2, pp 214-222.

Bronner, F. and Hoog, R. (2012), 'Economizing strategies during an economic crisis', Annals of Tourism Research, Vol 39, No 2, pp 1048-1069.

Christiansen, T. and Snepenger, D.J. (2002), 'Is it the mood or the mall that encourages tourists to shop?', Journal of Shopping Center Research, Vol 9, No 1, pp. 7-26.

Coles, T. (2004), 'Tourism and retail transactions: Lessons from the Porsche experience', Journal of Vacation Marketing, Vol 10, No 4, pp 378-389.

Dimanche, F. (2003), 'The Louisiana tax free shopping program for international visitors: a case study', Journal of Travel Research, Vol 41, No 3, pp 311-314.

Dudding, V. and Ryan, C. (2000), 'The impacts of tourism on a rural retail sector: a New Zealand case study', Tourism Economics, Vol 6, No 4, pp 301-319.

Garb, Y. (2007), 'The impact of retail deconcentration on travel to hypermarkets in Prague', in Razin, E., Dijst, M. and Vázquez C. eds, Employment Deconcentration in European Metropolitan Areas, The GeoJournal Library 91, Springer, Dordrecht, pp 235-264.

Hampson, D. and McGoldrick, P. (2011), 'A typology of adaptive shopping patterns in recession', Journal of Business Research, doi:10.1016/j.jbusres.2011.06.008 
HCSO (2011a), Jelentés a turizmus 2010. évi teljesitményéröl, HCSO, Budapest.

HCSO (2011b), Győr-Moson-Sopron megye statisztikai évkönyve, HCSO, Győr.

HCSO (2011c), Komárom-Esztergom megye statisztikai évkönyve, HCSO, Tatabánya.

HCSO (2011d), Vas megye statisztikai évkönyve, HCSO, Szombathely.

HCSO (2010), Jelentés a turizmus 2009. évi teljesítményéről, HCSO, Budapest.

HCSO (2009), Jelentés a turizmus 2008. évi teljesítményéről, HCSO, Budapest.

HCSO (2008), Jelentés a turizmus 2007. évi teljesítményéről, HCSO, Budapest.

HCSO (2007), Jelentés a turizmus 2006. évi teljesítményéről, HCSO, Budapest.

Henderson, J., Chee, L., Mun Ngai, C. and Lee, C. (2011), 'Shopping, tourism, retailing in Singapore', Managing Leisure, Vol 16, No 1, pp 36-48.

HNB (2011), Árfolyamok, http://www.mnb.hu/arfolyam-lekerdezes.

Hobson, P. S. J. (1996), 'Leisure shopping and tourism: the case of the South Korean market to Australia', Turizam, Vol 44, No 9-10, pp 228-244.

Hsieh, A. and Chang, J. (2006), 'Shopping and Tourist Night Markets in Taiwan', Tourism Management, Vol 27, No 1, pp 138-145.

Irimiás, A. (2009), ‘Az új kínai migráció: a Budapesten élő kínai közösség’, Statisztikai Szemle, Vol 87, No 7-8, pp 829-847.

Jansen-Verbeke, M. (1998), 'The synergism between shopping and tourism', in Theobald, W. F. ed, Global Tourism: The Next Decade, $2^{\text {nd }}$ ed, Butterworth-Heinemann, Oxford, pp 428-446.

Keller, M. (2005), 'Needs, desires and the experience of scarcity: representations of recreational shopping in post-Soviet Estonia', Journal of Consumer Culture, Vol 5, No 1, pp 65-85. 
Kemperman, A. D. A. M., Borgers, A. W. J. and Timmermans, H. J. P. (2009), 'Tourist shopping behavior in a historic downtown area', Tourism Management, Vol 30, No 2, pp 208-218.

Kim, S. and Prideaux, B. (1999), 'Korean inbound tourism to Australia - A study of supplyside deficiencies', Journal of Vacation Marketing, Vol 5, No 1, pp 66-81.

Ko, T. G. (2000), 'The issues and implications of escorted Shopping tours in a tourist destination region: the case study of Korean package tourists in Australia', Journal of Travel \& Tourism Marketing, Vol 8, No 3, pp 71-80.

Kovács, A. (2008), ‘A kiskereskedelem területi jellegzetességei a szlovák-magyar határtérségben', Tér és Társadalom, Vol 22, No 3, pp 97-107.

Lehto, X. Y., Cai, L. A., O’Leary, J. T. and Huan, T-C. (2004), 'Tourist shopping preferences and expenditure behaviours: The case of the Taiwanese outbound market', Journal of Vacation Marketing, Vol 10, No 4, pp 320-332.

Lesser, J. A. and Hughes, M. A. (1986), 'Towards a typology of shoppers', Business Horizons, Vol. 29, No 6, pp 56-62.

Luthar, B. (2006), 'Remembering socialism: on desire, consumption and surveillance', Journal of Consumer Culture, Vol 6, No 2, pp 229-259.

Marshall, A. (1890), Principles of Economics, Macmillan and Co. Ltd., London.

Michalkó, G. (2012), 'Kacattúra - utazó használtcikkek a turizmus és a kereskedelem változó világában', in Berta, P., ed, Használtcikk-kultúrák a rendszerváltás utáni KözépEurópában, L’Harmattan, Budapest, pp 200-220.

Michalkó, G. (2004), A bevásárlóturizmus, Kodolányi János Főiskola, Székesfehérvár.

Michalkó, G. (2002), ‘Országkép és kiskereskedelem: a külföldi turisták szabadidős vásárlásai a magyarországi idegenvezetők szemével', Turizmus Bulletin, Vol 6, No 3, pp $22-29$. 
Michalkó, G., Colombino, A. and Minca, C. (2005), 'Il turismo da shopping frontaliero: un confronto tra Lenti (Ungheria) e Trieste (Italia)', Turistica, Vol 14, No 2, pp 81-100.

Michalkó, G. and Rátz, T. (2006), 'Typically female features in Hungarian shopping tourism’, Migracijske i Etničke Teme, Vol 22, No 1-2, pp 79-93.

Michalkó, G. and Timothy, D. (2001), 'Cross-border shopping in Hungary: causes and effects', Visions in Leisure and Business, Vol 20, No 1, pp 4-17.

Michalkó, G. and Váradi, Zs. (2004), 'Croatian shopping tourism in Hungary: the case study of Barcs', Tourism, Vol 52, No 4, pp 351-359.

Moscardo, G. (2004), 'Shopping as a destination attraction: An empirical examination of the role of shopping in tourists' destination choice and experience', Journal of Vacation Marketing, Vol 10, No 4, pp 294-307.

Murphy, L., Benckendorff, P., Moscardo, G. and Pearce, P. (2012), Tourist Shopping Villages. Forms and Functions, Routledge, London.

Nagy, E. (2000), 'Globális stratégiák és lokális válaszok a kiskereskedelemben’, in Horváth, Gy. and Rechnitzer, J., eds, Magyarország területi szerkezete és folyamatai az ezredfordulón, MTA RKK, Pécs, pp 354-373.

Oh, J. Y-J., Cheng, C-K., Lehto X. Y. and O'Leary, J. T. (2004), 'Predictors of tourists shopping behaviour: Examination of socio-demographic characteristics and trip typologies', Journal of Vacation Marketing, Vol 10, No 4, pp 308-319.

Pál, Á. and Pál, V. (2007), ‘A határ menti fekvés hatása a szegedi kereskedelem térbeliségére', in Sikos T., T., ed, A bevásárlóközpontok jelene és jövője, Selye János Egyetem Kutatóintézete, Komárom, pp 278-286.

Rabbiosi, C. (2011), 'The invention of shopping tourism. The discursive repositioning of landscape in an Italian retail-led case', Journal of Tourism and Cultural Change, Vol 9, No 2, pp 70-86. 
Rátz, T. and Puczkó, L. (2002), The Impacts of Tourism: An Introduction, Häme Polytechnic, Hämeenlinna.

Reisinger, Y. and Turner, L. (2002), 'The determination of shopping satisfaction of Japanese tourists visiting Hawaii and the Gold Coast compared', Journal of Travel Research, Vol 41, No 2, pp 167-176.

RNB (2011), Exchange rates, http://www.bnro.ro/Exchange-rates-1224.aspx.

Saayman, M. and Saayman, A. (2012), 'Shopping tourism or tourists shopping? A case study of South Africa's African tourism market', Tourism Economics, Vol 18, No 6, pp 13131329.

Sikos T., T. and Kovács, A. (2008), 'Új trendek a határ menti kiskereskedelemben DélnyugatSzlovákiában', Területi Statisztika, Vol 11, No 6, pp 724-733.

Sikos T., T. and Tiner, T. (2007), Egy város - két ország: Komárom-Komárno, Selye János Egyetem Kutatóintézete, Komárom.

Snepenger, D. J., Murphy, L., O’Connell, R. and Gregg, E. (2003), 'Tourists and residents use of a shopping space', Annals of Tourism Research, Vol 30, No 3, pp 567-580.

Švab, A. (2002), 'Consuming Western images of well-being - shopping tourism in socialist Slovenia', Cultural Studies, Vol 16, No 1, pp 63-79.

Swanson, K. and Horridge, P. (2004), 'A structural model for souvenir consumption, travel activities, and tourist demographics', Journal of Travel Research, Vol 42, No 4, pp 372380.

Timothy, D. (2005), Shopping Tourism, Retailing and Leisure, Channel View Publications, Clevedon.

Timothy, D. J. and Butler, R. (1995), 'Cross-border shopping: a North American perspective', Annals of Tourism Research, Vol 22, No 5, pp 16-34.

Tréboul, B. (1994), ‘Tourisme et commerce à Troyes', Espaces, No 128, pp 14-23. 
Tömöri, M. (2011), 'The role of the "DebOra" cross-border Eurometropolis in the HungarianRomanian CBC relations: a case study of shopping tourism in Debrecen and Oradea', Eurolimes, Vol 11, pp 170-178.

Tömöri, M. (2012), 'Retail without borders: the example of Debrecen (Hungary) and Oradea (Romania)', Central European Regional Policy and Human Geography, Vol 3, No 1, pp $53-62$.

Yu, H. and Littrel, M. (2003), 'Product and process orientations to tourism shopping', Journal of Travel Research, Vol 42, No 2, pp 140-150. 
Figure 1. The seesaw model of shopping tourism

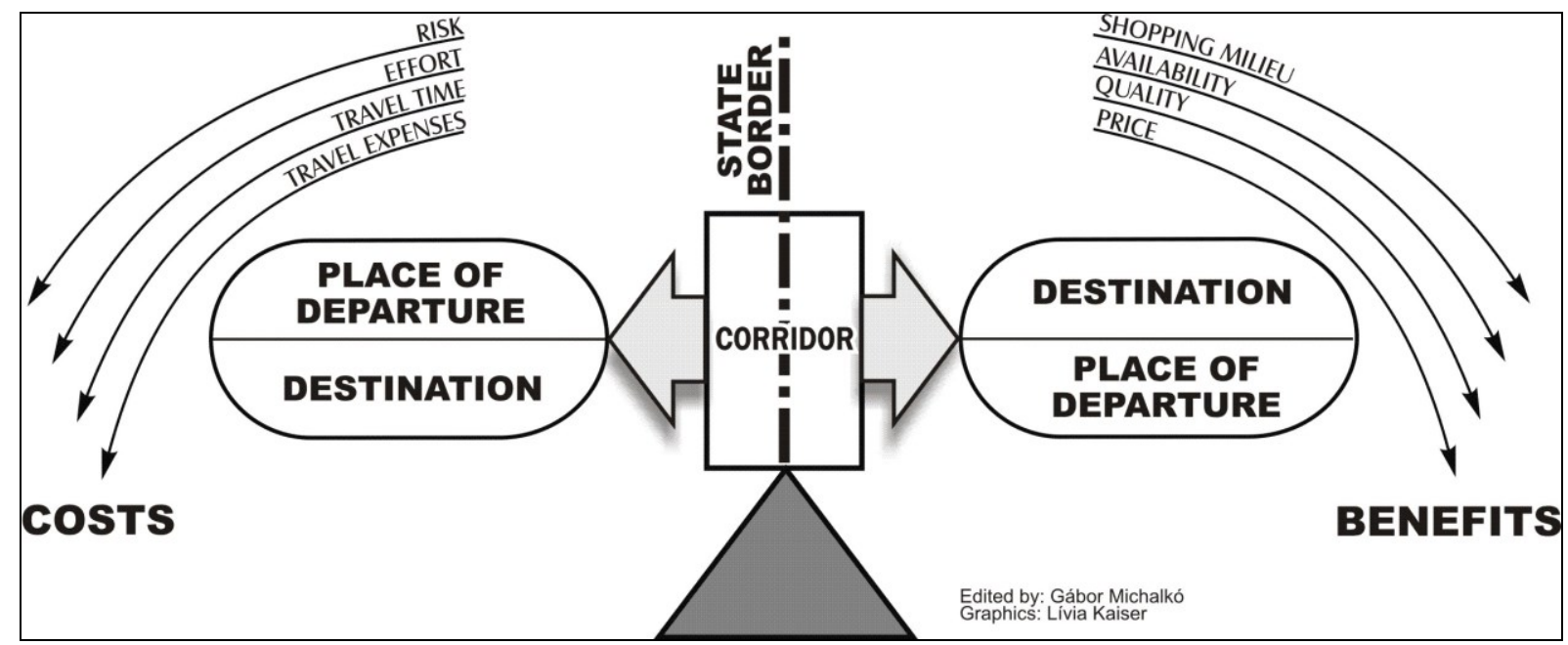

Source: Michalkó, 2012 
Figure 2. The role of shopping motivation in the tourist consumption of foreigners visiting Hungary, 2006-2010

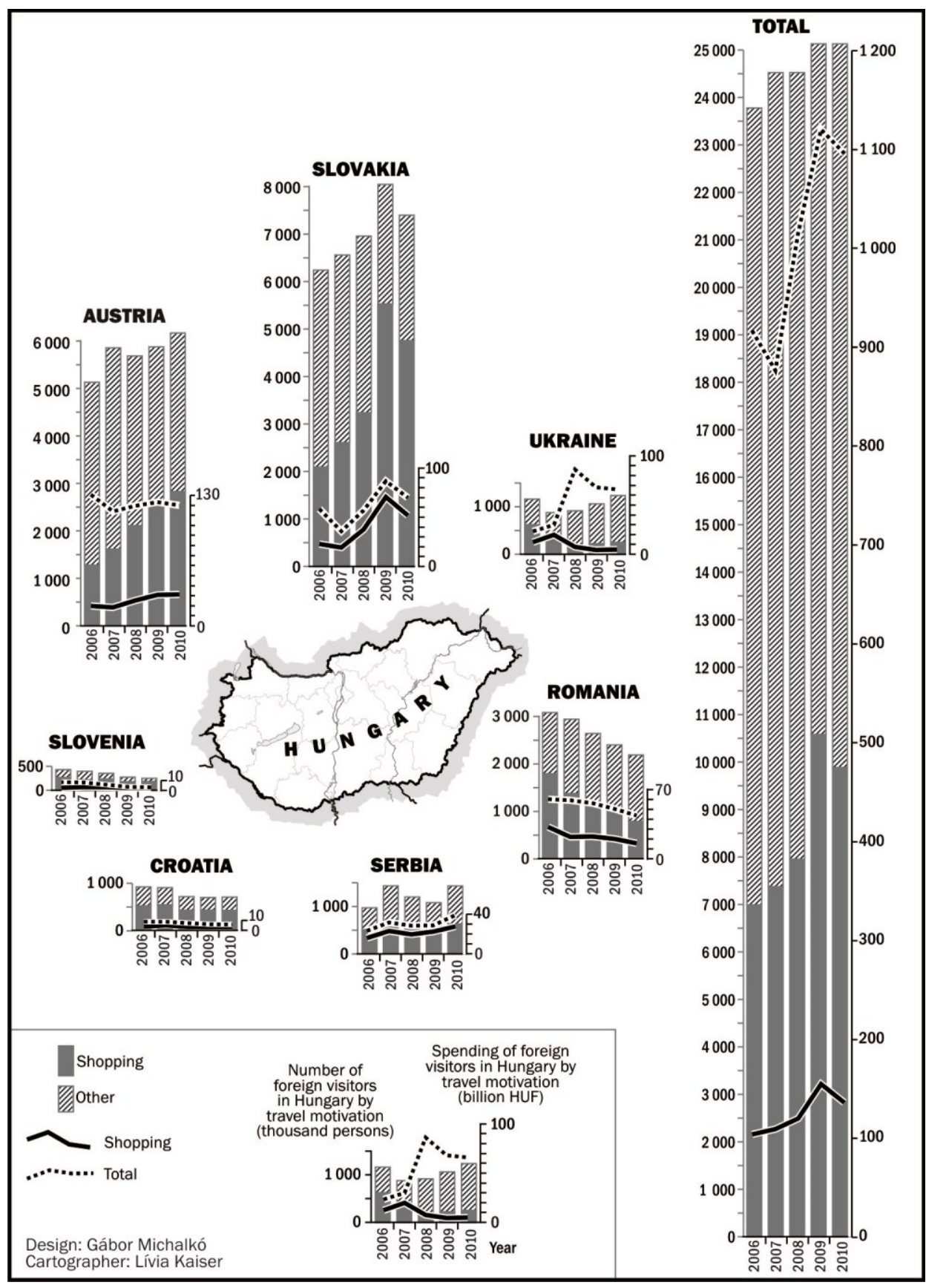

Source: HCSO, 2007-2011a 
Figure 3. Per capita spending of visitors arriving in Hungary, HUF (2006-2010)

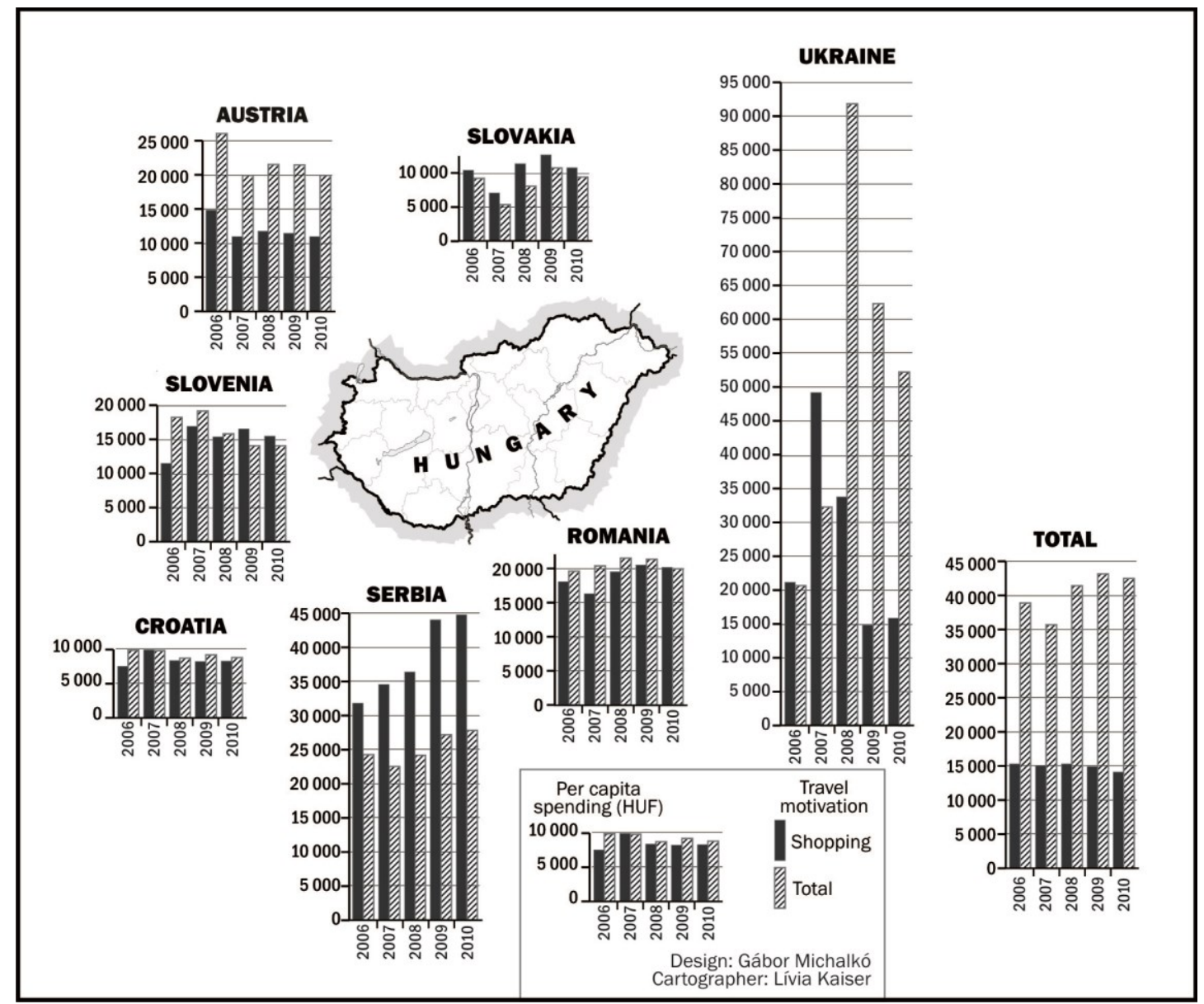

Source: HCSO, 2007-2011a 
Figure 4. Number of residents per retail outlet in major shopping tourism destinations in Hungary (2006-2010)

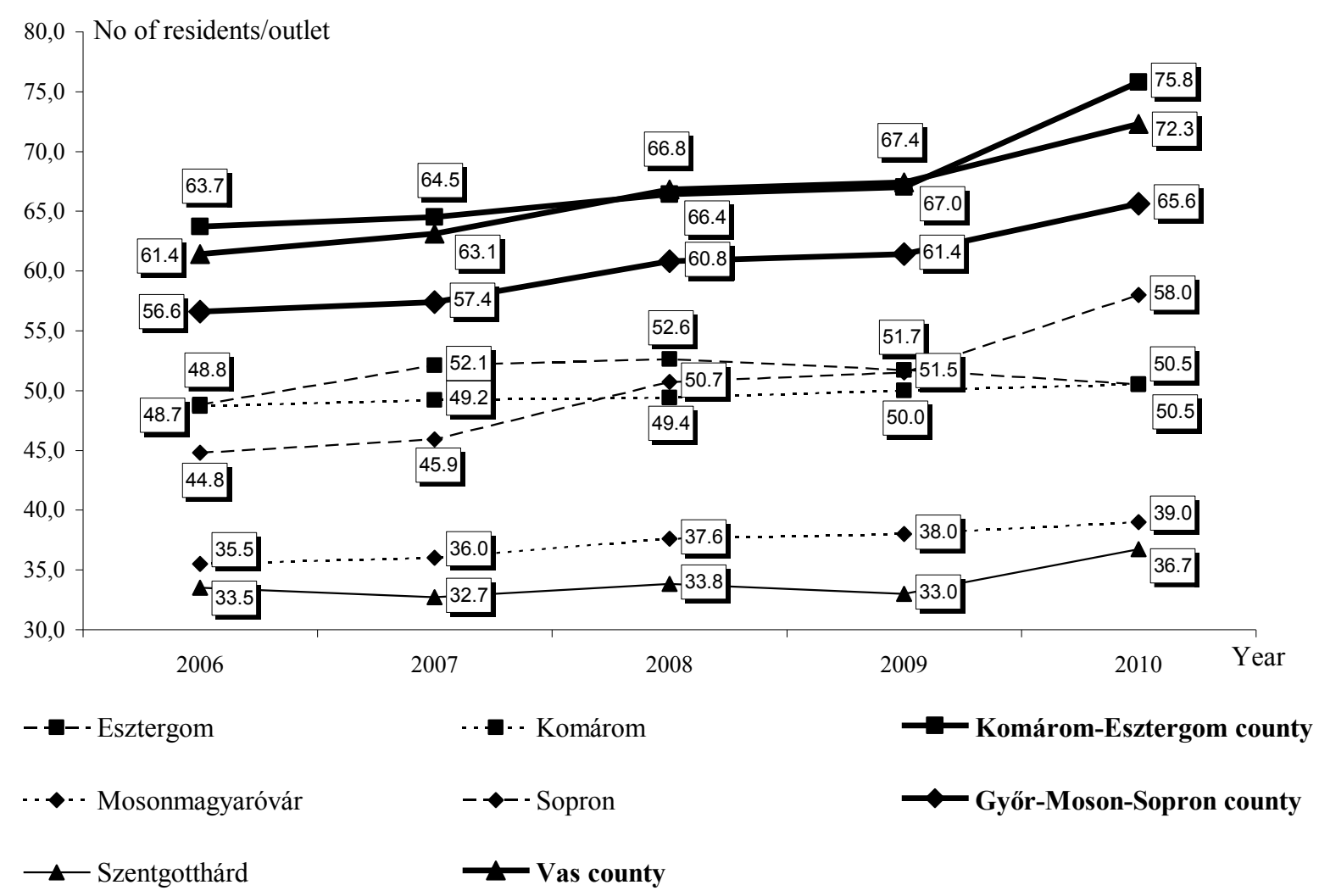

Source: HCSO, $2011 \mathrm{bcd}$ 
Figure 5. The number of day trippers visiting Hungary and the EUR/HUF exchange rate

$$
\text { (2006-2010) }
$$

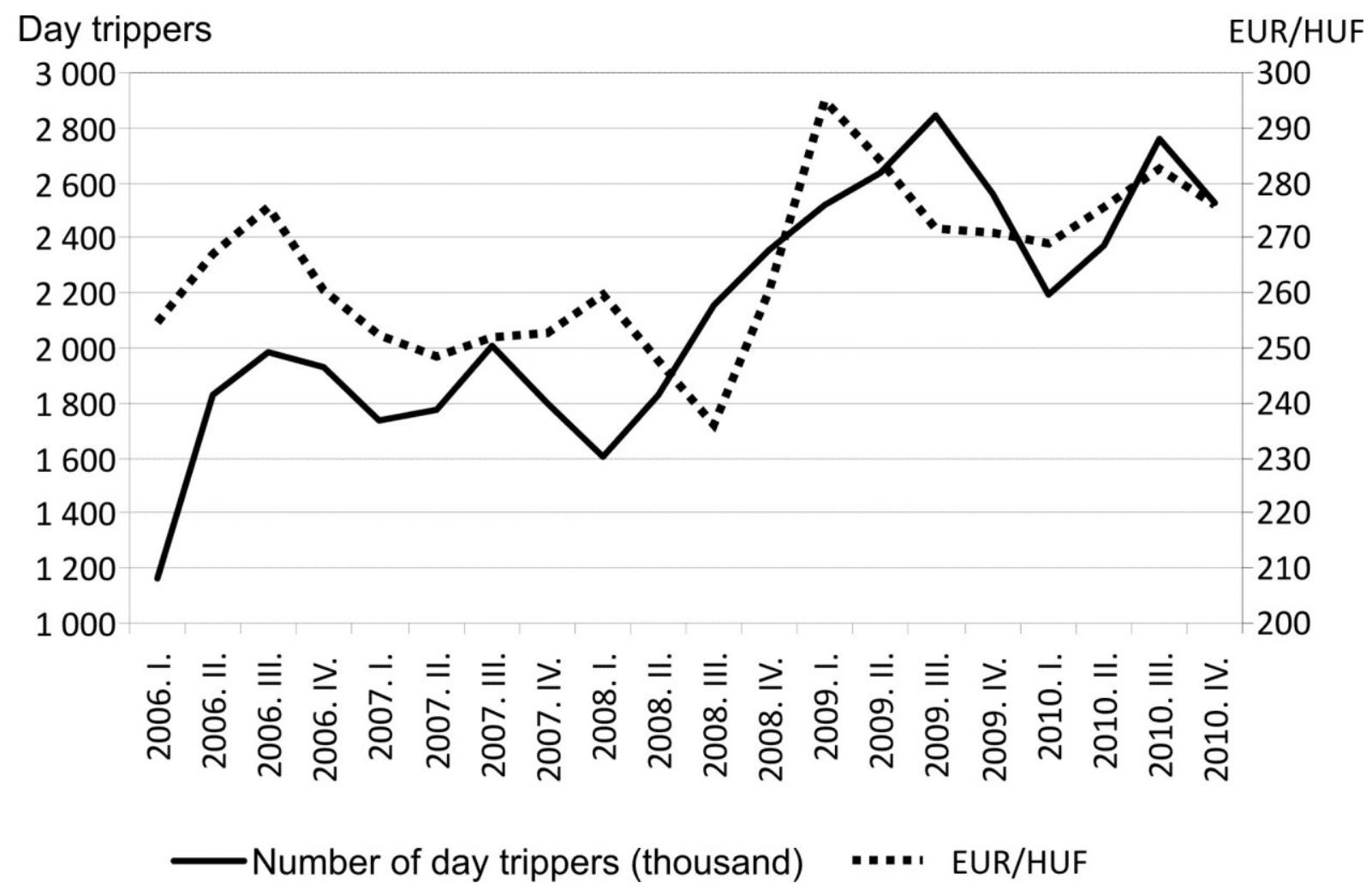

Source: Own calculation based on HCSO, 2007-2011a; HNB, 2011 
Table 1 . The dynamics of foreigners visiting Hungary (previous year $=100 \%$ )

\begin{tabular}{|l|c|c|c|c|}
\hline Visitors total & $\mathbf{2 0 0 7}$ & $\mathbf{2 0 0 8}$ & $\mathbf{2 0 0 9}$ & $\mathbf{2 0 1 0}$ \\
\hline Visitors with shopping motivation & 102.8 & 100.4 & 102.7 & 98.2 \\
\hline Day trippers & 105.5 & 108.3 & 132.9 & 93.3 \\
\hline Day trippers with shopping motivation & 105.8 & 100.0 & 102.7 & 96.3 \\
\hline Visitors total & 105.8 & 108.4 & 132.9 & 93.4 \\
\hline
\end{tabular}

Source: HCSO, 2008-2011a

Table 2. Consumption structure of foreigners visiting Hungary, 2007-2010 (\%)

\begin{tabular}{|l|r|r|r|r|}
\hline & \multicolumn{1}{|c|}{$\mathbf{2 0 0 7}$} & \multicolumn{1}{c|}{$\mathbf{2 0 0 8}$} & \multicolumn{1}{|c|}{$\mathbf{2 0 0 9}$} & \multicolumn{1}{|c|}{$\mathbf{2 0 1 0}$} \\
\hline Dining in restaurants & 1.9 & 2.1 & 2.3 & 2.5 \\
\hline Food and beverages purchased in store & 27.2 & 36.6 & 49.2 & 46.5 \\
\hline Fuel & 0.3 & 0.7 & 1.3 & 0.5 \\
\hline Other gifts & 54.4 & 54.3 & 44.4 & 47.3 \\
\hline Other expenditure & 16.2 & 6.3 & 2.8 & 3.2 \\
\hline Total & 100.0 & 100.0 & 100.0 & 100.0 \\
\hline
\end{tabular}

Source: HCSO, 2008-2011a 
Table 3. The number of retail outlets in the main shopping tourism destinations along the Slovakian- Hungarian and the Austrian-Hungarian borders (2006-2010)

\begin{tabular}{|l|r|r|r|r|r|}
\hline & $\mathbf{2 0 0 6}$ & $\mathbf{2 0 0 7}$ & $\mathbf{2 0 0 8}$ & $\mathbf{2 0 0 9}$ & $\mathbf{2 0 1 0}$ \\
\cline { 2 - 6 } & Outlets & Outlets & Outlets & Outlets & Outlets \\
\hline Esztergom & 620 & 586 & 588 & 598 & 611 \\
Komárom & 402 & 398 & 400 & 394 & 391 \\
Komárom-Esztergom county & 4945 & 4877 & 4736 & 4660 & 4110 \\
\hline Sopronmagyaróvár & 886 & 883 & 858 & 857 & 846 \\
Györ-Moson-Sopron county & 7819 & 7743 & 7349 & 7303 & 6856 \\
\hline Szentgotthárd & 270 & 275 & 265 & 269 & 241 \\
Vas county & 4288 & 4150 & 3908 & 3849 & 3531 \\
\hline
\end{tabular}

Source: HCSO, $2011 \mathrm{bcd}$ 